\title{
Gençlik Hizmetleri Ve Spor İl Müdürlüğü Çalışanlarının, Duygusal Zeka İle Örgütsel Vatandaşlık Davranışlarının İncelenmesi ${ }^{1}$
}

DOI: 10.26466/opus.624515

\author{
Sultan Yavuz Eroğlu* - Erdem Eroğlu ${ }^{* *}$ - Servet Reyhan***
}

* Dr. Öğr. Üyesi,. Siirt Üniversitesi, Beden Eğitimi ve Spor Yüksekokulu / Siirt/ Türkiye

E-Posta: sultanyavuzeroglu@siirt.edu.tr ORCID: 0000-0002-6301-9257

** Dr. Öğr. Üyesi, Siirt Üniversitesi, Beden Eğitimi ve Spor Yüksekokulu / Siirt/ Türkiye

E-Posta: erdemeroglu@siirt.edu.tr ORCID: 0000-0001-5875-2836

*** Dr. Öğr. Üyesi,. Siirt Üniversitesi, Beden Eğitimi ve Spor Yüksekokulu / Siirt/ Türkiye

E-Posta: servet.reyhan@siirt.edu.tr ORCID: 0000-0003-3303-7566

\section{Öz}

Bu çalışmanın amacl; Genclik ve Spor Il Müdürlügü calışanlarmın örgütsel vatandaşlk ile duygusal zeka davranışları arasındaki ilişkinin belirlenmesidir. Araştırma da veri toplama tekniği olarak, araştırmacılar tarafindan oluşturulan kişisel bilgi formu, katılımciların duygusal zeka düzeylerini ölçmek için Özaslan, Acar B. ve Acar C. (2009) tarafindan geliştirilen 25 ifadeden oluşan "Duygusal Zeka Ölçeği" ile Örgütsel vatandaşlı davranışlarmı ölçmek üzere Morrison tarafindan (1994) geliştirilen ve Türker, Yenerli ve Aksoy (2006) tarafindan Türkçeye uyarlanmış örgütsel vatandaşlı ölçeğinin kısaltılmış formu kullanılmıştır. Verilerin analizinde, ikili karşılaştırmalarm tespiti için T-Testi ikiden fazla bağımsız değgişkenler ile bağıml değişkenler arasındaki farkın tespiti için ANOVA testi kullanılmıştır. "Örgütsel Vatandaşlık Davranış" ölçeği alt boyutlarn ile "Duygusal Zeka" ölçeği alt boyutlarnna ilişkin ilişkiye bakmak için ise pearson korelasyon analizi yapılmıştır. Sonuç olarak; örgütsel vatandaşlı alt boyutları ile yapılan analizlerde cinsiyet, medeni durum, iş deneyimi değiş̧kenlerinde anlaml farklllk $(p>0,05)$ görülmemişken, yaş değişkeninde anlaml farklllık $(p<0,05)$ görülmüştür. Duygusal zekâ ölçeği alt boyutları ile yapılan analiz sonuçlarında ise, yaş ile medeni durum değişsenlerinde anlaml farkllık $(p>0,05)$ bulunmamışken, cinsiyet, öğrenim durumu ve iş deneyimi değişkenlerinde anlamlı farklllık $(p<0,05)$ görülmüştür. Ayrıca yapılan korelasyon analizi sonucunda duygusal zeka alt boyutlarn ile örgütsel vatandaşlı alt boyutları arasında düşük düzeyde pozitif ve anlamlı bir ilişki olduğu görülmüştür.

Anahtar Kelimeler: Gençlik Hizmetleri ve Spor İl Müdürlüğ̈̈, Örgüt, Örgütsel Vatandaşlık, Duygusal Zekâ

${ }^{1}$ Bu çalışma 11-14 Nisan 2019 tarihlerleri arasında Bodrum-Türkiyede Düzenlenen 2. Uluslararsı Rekreasyon ve Spor Yönetimi Kongresinde sözlü bildiri olarak sunulmuştur. 


\title{
Investigation Of Emotional And Sports Provincial Directorate Employees 'Emotional And Organizational Citizenship Behavior
}

\begin{abstract}
The aim of this study; Provincial Directorate of Youth and Sports employees to determine the relationship between organizational citizenship and emotional intelligence behaviors. As a research data collection technique, the personal information form created by the researchers, 25 Emotional Intelligence Scale 25 which was developed by Özaslan, Acar B. and Acar C. (2009) in order to measure the emotional intelligence levels of the participants and Morrison (2006) were used to measure organizational citizenship behaviors. 1994), which is developed by Türker, Yenerli and Aksoy (2006). In the analysis of the data, T-Test was used for the determination of binary comparisons and ANOVA test was used for the determination of the difference between more than two independent variables and dependent variables. Pearson correlation analysis was used to look at the relationship between the subscales of Davranis Organizational Citizenship Behavior "and alt Emotional Intelligence" subscales. As a result; While there were no significant differences ( $p>0.05$ ) in gender, marital status, and work experience variables in the analyzes conducted with organizational citizenship sub-dimensions, there was a significant difference in age variable $(p<0.05)$. There was no significant difference in age and marital status variables ( $p>0.05)$, but there was a significant difference in gender, educational status and work experience ( $p$ $<0.05)$. In addition, as a result of the correlation analysis, there was a low positive and significant relationship between emotional intelligence sub-dimensions and organizational citizenship sub-dimensions.
\end{abstract}

Keywords: Provincial Directorate of Youth Services and Sports, Organization, Organizational Citizenship, Emotional Intelligence 


\section{Giriş}

Günümüzde küresellesme ile birlikte siyasal, toplumsal, kültürel ve spor alanlarında birçok değişim ve gelişim olduğu herkesçe bilinmektedir. Şüphesiz ki bu gelişim ve değişimler daha çok örgütlerde görülmektedir. Örgütlerin ayakta kalabilmesi ve başarıyı yakalabilmesi için bu değişime ayak uydurmaları, sürekli yeniliği benimsemeleri ve doğru zamanda doğru işi yapan personelle çalışmaları gerekmektedir. Aynı zamanda, örgütlerin ana kaynağı insan olduğundan çalışandan yöneticiye kadar herkesin iş birliği içerisinde aynı amaca hizmet etmeleri beklenmektedir. Şüphesiz ki örgüt çalışanlarının uyumu yakalamaları motivasyonu arttırarak örgüte katkı sağlayacaktır. Literatürde pek çok örgüt tanımı mevcuttur. Bu tanımlara bakıldığında, örgütten bahsetmek için, en az iki kişiden oluşan belli bir amaca yönelik koordinatif bir şekilde vucut bulan yapılar olarak tanımlanmıştır. En az iki kişi olması ve koordinatif bir durumu içermesi örgütlerde insan unsurunu ön plana çıartmıştır. Bu sebep ile örgütlerin varlıklarını sürdürebilmesi için örgüt içinde iş görenlerin örgüte bağlılıkları önemli bir unsurdur (Kürekli, 2011; Başaran, 1984; Şimşek, 1999). Bu doğrultuda, örgütsel vatandaşlık davranışı kavramının gündeme gelmesi söz konusu olmuştur.

Örgütsel vatandaşlık davranışının birçok farklı değişken ile ilişkisi incelenmiştir. Bireyin örgüt yararına sergilediği/sergilemek istediği davranışların ve örgüte aidiyetin derecesini ifade etmek için kullanılan bir kavramdır. Örgütsel vatandaşlık davranışının kemikleştiği örgütlerde çalışanların örgütsel bağlllık derecesi yüksek olmakta, işten ayrılma eğilimleri az olmakta, örgüt yararına davranışlar sergileme potansiyeli ise artmaktadır. Her örgüt, vatandaşlık davranışı gelişmiş bireyler istihdam etmek ister. Bunu sağlamak için ise gerekli zemini hazırlamak örgütlerin en temel görevleri arasında olmal1dır (Güllü ve Şahin, 2018). Örgütsel vatandaşlık davranışı bicimsel ödül sistemi tarafından doğrudan ya da açık olarak tanımlanmayan, zorlayıcı olmayan ve örgütün fonksiyonların bir bütün olarak daha etkin bicimde yerine getirmesine destek olan gönüllü birey davranışlarıdır (Organ ve Dennis, 1997). Örgütsel vatandaşlık davranışının görülmesi için gerekli en temel unsur zorlama olmadan iş görenin kişisel arzusuyla hareket etmesidir. Örgütsel vatandaşlık davranışı, gönüllü çalışanlar tarafından düşük iş stresi, çatısma seviyesi, iş devamsızlığı ile yüksek performans gibi olumlu etkiler yaratacağı 
düşünülmektedir (Çelik ve Çıra, 2013). Bütün insanlarda sevdiği kişi ve kurumlara karşı onu benimseme ve bağlllık güdüsü önemli bir yer tutmaktadır. Bu güdü gelişemediği ya da yöneticilerce geliştirilemediği takdirde, çalışanların örgütsel iş ve performansları düşmekte, işten ayrılma, duygu, düşünce ve tutumları artmaktadır ( Karayol, 2019). Kişinin örgüt içinde bu hareket tarzını belirleyebilmesi karşılıklı iletişimi kolaylaştırdığı gibi çabuk karar verme ve strateji geliştirmede de etkili olduğu söylenebilir. Dolayısıyla yöneticilerin, örgüt içerindeki uyum ve performansın yüksek olmasını sağlayabilmeleri için, durumsal algıları anlayabilme ve algısal niteliklerini geliştirmeleri gerekmektedir. Bu anlamda yöneticilerin geliştirilebilen özellikte bir zekâ türü olan ve insan ilişkilerinde kolaylık sağlayan duygusal zekayı önemsemeleri gerekmektedir (Çakar ve Arbak, 2004).

Duygusal zeka tanımına bakmadan önce zekanın tanımına bakmak yerinde olacaktır. Türk Dil Kurumu zekayı; İnsanın düşünme, akıl yürütme, objektif gerçekleri algılama, yargılama ve sonuç çıkarma yeteneklerinin tamami, anlak, dirayet, zeyreklik, feraset olarak tanımlamaktadır (https://sozluk.gov.tr). . Hiç şüphesiz zekanın gelişmesinde pekçok etken söz konusudur. Bu etkenlerden en önemlisi olarak insanların Çevre ile etkileşimini söylemek mümkünüdür. Çünkü çevre ile etkileşim insanların zeka ve dil gelişimi üzerinde rol oynayan önemli bir faktördür (Özen ve ark. 2018). Gerek örgütlerde çalışanların örgüt için, gerekse insanların kendi hayatlarındaki kazanımları için, yukarıda yeralan zeka tanımındaki gibi akıl yürütme, objektif gerçekleri algılama, yada sonuç çıkarma yetenekleri önem arz etmektedir. Ayrıca, insanların bu bahsedilen özelliklerini tek bir yönde yapmaları mümkün olmayabilir yani kimi insanlar analitik yönden sonuç çıkarabiliyorkan kimi insanlar sosyal veya duygusal yönden sonuç çıkarabilir.

Duygusal zekâ; duyguları algılama ve ifade etme, duyguları düşünce içinde özümseyebilme, duygularla anlayabilme ve sorgulayabilme, kendinde ve başkalarındaki duyguları düzenleyebilme yeteneği olarak tanımlanabilir (Mayer ve ark. 2004). Goleman'a göre duygusal zekâ; kişinin kendinin ve başkalarının duygularını tanıması ve anlaması; kendini motive etmesi; kendi içinde ve ilişkilerinde duygularını doğru yönetmesiyle ilgili yetenektir (Goleman, 1995). Toplumsal faydanın yanı sıra ülke prestiji açısından önemli görülen spor kurumları çalışanlarını örgütsel vatandaşlık davranışı sergilemeleri ve hiyerarşik düzen içerisinde dugusal zeka davranışlarının olması bu kurumun başarısı için önemli görülmektedir. Araştırmamızda; duygusal 
zeka ve örgütsel vatandaşlık düzeylerinin bazı değişkenler (cinsiyet, yaş, iş deneyimi, öğrenim durumu) açısından farklılaşmaktadır $\left(\mathrm{H}_{1}\right)$ ve duygusal zeka ile örgütsel vatandaşlık arasında pozitif bir ilişki vardır $\left(\mathrm{H}_{2}\right)$ şeklinde ortaya koyduğumuz hipotezlerimiz doğrultusunda, gençlik hizmetleri ve spor il müdürlüğü çalışanlarının, duygusal zeka ile örgütsel vatandaslık davranışlarının incelenmesi amaçlanmıştır.

\section{Materyal ve Metod}

\section{Araştırma Modeli}

Genclik ve Spor İl Müdürlügü calışanlarının örgütsel vatandaşlık ile duygusal zeka davranışları arasındaki ilişkinin belirlenmesini amaçlayan bu araştırmada nicel araştırma yöntemlerinden betimsel tarama modeli kullanılmıştır. Betimsel tarama, bir değişkene ilişkin sayısal değerlerin toplanması, betimlenmesi ve sunulmasına olanak sağlayan istatistiksel işlemlerdir (Büyüköztürk ve ark. 2014).

\section{Araştırma Grubu}

Araştırmanın evrenini Gençlik Hizmetleri ve Spor İl Müdürlüğün'de çalışan bireyler oluşturmaktadır. Kolayda örnekleme yöntemiyle Kütahya, Adana, Ankara, Afyon, Eskişehir illerinde gönüllü olarak çalışmaya katılan 50 Kadın, 104 Erkek olmak üzere toplamda 154 çalışan oluşturmaktadır. Çalışmaya katılan çalışanlara ölçme araçları açıklama yapılarak yüzyüze uygulanmıştır.

\section{Veri Toplama Araçları}

Bu çalışmada veri toplama aracı olarak anket yöntemi kullanılmıştır. Anketin ilk bölümünde katılımcıların demografik özelliklerini (cinsiyet, yaş, medeni durum, iş deneyimi, öğrenim durumu) tespit etmek için araştırmacılar tarafından oluşturulan kişisel bilgi formu kullanılmıştır. İkinci bölümünde ise; çalışmaya katılanların duygusal zeka düzeylerini tespit etmek için Özaslan ÖB, Acar B. ve Acar C. (2009) tarafından geliştirilen "duygusal farkındalık, "motivasyon", "kendini yönetme", "empeti”, "ilişki yönetimi" olmak üzere 
5 alt boyut ve 25 maddeden oluşan Duygusal Zeka ölçeği, üçüncü bölümünde de Morrison tarafından (1994) geliştirilen ve Türker, Yenerli ve Aksoy (2006) tarafından Türkçeye uyarlanmış "örgütsel gelişime katkı”, "yardımseverlik", "sahiplenme", "centilmenlik", "kendini gerçkleştirme" olmak üzere 5 alt boyut ve 21 maddeden oluşan örgütsel vatandaşlık ölçeğinin kısaltılmış formu kullanılmıştır.

\section{Verilerin Analizinde}

Verilerin analizi aşamasında analizler öncesinde verinin normal dağılıp dağılmadığı kontrol edilmiş ve Kolmogorow-Smirnov normallik testi sonucunda verinin normallik varsayımını karşıladığı belirlenmiştir $(\mathrm{p}<0,05)$. İkili karşılaştırmaların tespiti için bağımsız örneklem t-testi ikiden fazla bağımsız değişkenler ile bağımlı değişkenler arasındaki farkın tespiti için ANOVA testi kullanılmıştır. Ayrıca "Örgütsel Vatandaşlık Davranış” ölçeği ile “Duygusal Zeka" ölçeklerinin alt boyutları arasındaki ilişkinin tespiti için Korelasyon analizi yapılmıştır.

\section{Bulgular}

Çalışmada elde edilen bulgular aşağıda yer alan tablolar şeklinde sunulmuştur.

Tablo 1. Katılımcıların Örgütsel Vatandaşlık Davramış Ölçeği Puanlarnnın Cinsiyet Değişkenine Göre T-Testi Sonuçları

\begin{tabular}{|c|c|c|c|c|c|c|c|}
\hline & Cinsiyet & $\mathrm{N}$ & $\mathrm{X}$ & $S$ & $\mathrm{Sd}$ & $\mathrm{t}$ & $\mathrm{p}$ \\
\hline \multirow{2}{*}{ Örgütsel Gelişime Katkı } & Kadın & 50 & 29,06 & 4,35 & 152 &,- 101 & ,920 \\
\hline & Erkek & 104 & 29,14 & 5,07 & & & \\
\hline \multirow{2}{*}{ Yardımseverlik } & Kadın & 50 & 22,58 & 3,57 & & -670 & ,504 \\
\hline & Erkek & 104 & 22,95 & 3,05 & & & \\
\hline \multirow{2}{*}{ Sahiplenme } & Kadın & 50 & 12,54 & 1,88 & & ,193 & 847 \\
\hline & Erkek & 104 & 12,47 & 2,16 & & & \\
\hline \multirow{2}{*}{ Centilmenlik } & Kadın & 50 & 6,80 & 1,46 & & ,351 & ,726 \\
\hline & Erkek & 104 & 6,70 & 1,69 & & & \\
\hline \multirow{2}{*}{ Kendini Gerçekleştirme } & Kadın & 50 & 7,88 & 1,72 & & ,207 & 836 \\
\hline & Erkek & 104 & 7,83 & 1,37 & & & \\
\hline
\end{tabular}

Analiz sonuçları katılımcıların örgütsel vatandaşlık ölçeği alt boyutları cinsi- 
yet değişkenine göre örgütsel gelişime katk1, $t(152)=-, 101, p>0,05$, yardımseverlik, $t(152)=-, 670, p>0,05$, sahiplenme $t(152)=, 193, p>0,05$ ve centilmenlik, $t(152)=, 351, p>0,05$ ve kendini gerçekleştirme $t(152)=, 207, p>0,05$ cinsiyete göre anlamlı bir farklılık göstermemektedir.

Tablo 2. Katılımcıların Örgütsel Vatandaşlık Davranış Ölçeği Puanlarının Medeni Durum Değişkenine Göre T-Testi Sonuçlarn

\begin{tabular}{|c|c|c|c|c|c|c|c|}
\hline & Medeni Durum & $\mathrm{N}$ & $X$ & $S$ & $\mathrm{Sd}$ & $\mathrm{t}$ & $\mathrm{p}$ \\
\hline \multirow{2}{*}{ Örgütsel Gelişime Katkı } & Evli & 92 & 28,68 & 5,40 & 152 & $-1,36$ & , 177 \\
\hline & Bekar & 62 & 29,76 & 3,80 & & & \\
\hline \multirow{2}{*}{ Yardımseverlik } & Evli & 92 & 22,84 & 3,42 & & ,03 & ,978 \\
\hline & Bekar & 62 & 22,82 & 2,93 & & & \\
\hline \multirow{2}{*}{ Kendini Gerçekleştirme } & $\underline{\text { Evli }}$ & 92 & 7,90 & 1,45 & &, 59 &, 557 \\
\hline & Bekar & 62 & 7,76 & 1,55 & & & \\
\hline \multirow{2}{*}{ Sahiplenme } & Evli & 92 & 12,71 & 2,06 & & 1,57 & ,119 \\
\hline & Bekar & 62 & 12,18 & 2,05 & & & \\
\hline \multirow{2}{*}{ Centilmenlik } & $\underline{\text { Evli }}$ & 92 & 6,64 & 1,60 & &,- 86 & ,389 \\
\hline & Bekar & 62 & 6,87 & 1,64 & & & \\
\hline
\end{tabular}

Analiz sonuçları katılımcıların örgütsel vatandaşlık ölçeği alt boyutları medeni durum değişkenine göre örgütsel gelişime katkı, $t(152)=-1,36, p>0,05$, yardımseverlik, $t(152)=-, 03, p>0,05$, sahiplenme $t(152)=1,57, p>0,05$ ve centilmenlik, $t(152)=, 86, p>0,05$ ve kendini gerçekleştirme $t(152)=, 59, p>0,05$ cinsiyete göre anlamlı bir farklılık göstermemektedir.

Tablo 3. Katılımcıların Örgütsel Vatandaşlık Davranış Ölçeği Puanlarının İş Deneyimi Değişkenine Göre ANOVA Sonuçlarn

\begin{tabular}{|c|c|c|c|c|c|c|}
\hline & & Kareler Toplamı & Sd & Kareler Ortalaması & $\mathrm{F}$ & $\mathrm{P}$ \\
\hline & Gruplararası & 53,481 & 4 & 13,370 & ,566 & 688 \\
\hline \multirow[t]{3}{*}{ Örgütsel Gelişime Katkı } & Gruplariçi & 3520,415 & 149 & 23,627 & & \\
\hline & Toplam & 3573,896 & & & & \\
\hline & Gruplararası & 7,522 & & 1,880 & ,177 & ,950 \\
\hline \multirow[t]{3}{*}{ Yardımseverlik } & Gruplariçi & 1580,089 & & 10,605 & & \\
\hline & Toplam & 1587,610 & & & & \\
\hline & Gruplararası & 8,482 & & 2,120 & ,958 & , 432 \\
\hline \multirow[t]{3}{*}{ Kendini gerçekleştirme } & Gruplariçi & 329,778 & & 2,213 & & \\
\hline & Toplam & 338,260 & & & & \\
\hline & Gruplararası & 21,691 & & 5,423 & 1,281 & ,280 \\
\hline \multirow[t]{3}{*}{ Sahiplenme } & Gruplariçi & 630,803 & & 4,234 & & \\
\hline & Toplam & 652,494 & & & & \\
\hline & Gruplararası & 7,253 & & 1,813 & ,688 & ,601 \\
\hline \multirow[t]{2}{*}{ Centilmenlik } & Gruplariçi & 392,831 & & 2,636 & & \\
\hline & Toplam & 400,084 & & & & \\
\hline
\end{tabular}


Analiz sonuçları, katılımcıların örgütsel vatandaşlık alt boyutlarından örgütsel gelişime katkı $\mathrm{F}(4,149)=, 566, \mathrm{P}>0,05$, yardımseverlik $\mathrm{F}(4,149)=, 177$, $\mathrm{p}>0,05$, kendini gerçekleştirme $\mathrm{F}(4,149)=, 958, \quad \mathrm{p}>0,05$, sahiplenme $\mathrm{F}=(4,149)=1,281, \mathrm{p}>0,05$ ve centilmenlik $\mathrm{F}=(4,149), \mathrm{P}>0,05$ düzeyleri ile iş deneyimi arasında anlamlı bir farkın olmadığını göstermektedir.

Tablo 4. Katılımcıların Örgütsel Vatandaşlık Davranış Ölçeği Puanlarının Yaş Değişkenine Göre ANOVA Sonuçlan

\begin{tabular}{|c|c|c|c|c|c|c|}
\hline & & Kareler Toplamı & sd & Kareler Ortalaması & $\mathrm{F}$ & $\mathrm{P}$ \\
\hline \multirow{3}{*}{ Örgütsel Gelişime Katkı } & Gruplararası & 98,785 & 3 & 32,928 & 1,421 & ,239 \\
\hline & Gruplariçi & 3475,111 & 150 & 23,167 & & \\
\hline & Toplam & 3573,896 & 153 & & & \\
\hline \multirow{3}{*}{ Yardımseverlik } & Gruplararası & 2,044 & 3 & 681 & ,064 & ,979 \\
\hline & Gruplariçi & 1585,566 & 150 & 10,570 & & \\
\hline & Toplam & 1587,610 & 153 & & & \\
\hline \multirow{3}{*}{ Kendini Gerçekleştirme } & Gruplararası & 11,307 & 3 & 3,769 & 1,729 & 163 \\
\hline & Gruplariçi & 326,953 & 150 & 2,180 & & \\
\hline & Toplam & 338,260 & 153 & & & \\
\hline \multirow{3}{*}{ Sahiplenme } & Gruplararası & 37,928 & 3 & 12,643 & 3,086 & ,029 \\
\hline & Gruplariçi & 614,566 & 150 & 4,097 & & \\
\hline & Toplam & 652,494 & 153 & & & \\
\hline \multirow{3}{*}{ Centilmenlik } & Gruplararası & 8,111 & 3 & 2,704 & 1,035 & 379 \\
\hline & Gruplariçi & 391,973 & 150 & 2,613 & & \\
\hline & Toplam & 400,084 & 153 & & & \\
\hline
\end{tabular}

Tabloda görüldüŭğ gibi yaş açısından örgütsel vatandaşlık ölçeğinin örgütsel gelişime katkı alt boyutunda $\mathrm{F}(3,150)=1,124, \mathrm{p}>0,05$, yardımseverlik alt boyutunda $\mathrm{F}(3,150)=, 064$, $\mathrm{p}>0,05$, centilmenlik alt boyutunda $\mathrm{F}(3,150)=1,035$, $\mathrm{p}>0,05$ anlamlı farklılığa rastlanmamıştır. Örgütsel vatandaşlık ölçeğinin sahiplenme alt boyutunda $\mathrm{F}(3,150)=3,086 \mathrm{P}<0,05$ anlamlı farklılık görülmüştür. Anlamlı farkların elde edilmesinden sonra anlamlılığın hangi gruplardan kaynaklandığını tespit etmek için TUKEY Testi kullanılmıştır.

Tablo görüldüğü gibi katılımcıların yaş değişkenine göre algıladıkları örgütsel vatandaşlık alt boyutlarından sahiplenme puanları arasında istatistik olarak anlamlı farklılık vardır. Bu anlamlı farklılık 22-26 yaş grubu, 32-36 il 37 ve üzeri yaş gruplarından kaynaklandığı görülmektedir. Bu yaş gruplarının algıladıkları sahiplenme algısı diğer yaş gruplarına göre daha anlamlıdır. Ayrıca sıra ortalamalarına bakıldığında yaş gruplarından 22-26 yaşın diğer gruplara göre sahiplenme algılarının daha yüksek olduğu görülmektedir. 
Tablo 5. Örgütsel Vatandaşlık Ölçeği Puanlarının Yaşa Göre ANOVA Sonuçlarında Sahiplenme Alt Boyutundaki Anlamlı Farka İlişkin TUKEY Testi Sonuçları

\begin{tabular}{|c|c|c|c|c|}
\hline & & Ort. Fark. & ss & $\mathrm{p}$ \\
\hline \multirow{3}{*}{$22-26$} & $27-31$ & $-1,09470$ & ,52114 & 158 \\
\hline & $32-36$ & $-1,60606^{*}$ &, 55712 & ,023 \\
\hline & 37 ve üzeri & $-1,34225^{*}$ &, 51630 & , 050 \\
\hline \multirow{3}{*}{$27-31$} & $22-26$ & 1,09470 & ,52114 & , 158 \\
\hline & $32-36$ &,- 51136 & ,45772 & ,680 \\
\hline & 37 ve üzeri &,- 24755 & ,40705 & ,929 \\
\hline \multirow{3}{*}{$32-36$} & $22-26$ & $1,60606^{*}$ &, 55712 &, 023 \\
\hline & $27-31$ &, 51136 & 45772 & 680 \\
\hline & 37 ve üzeri & ,26381 & ,45221 & ,937 \\
\hline \multirow{3}{*}{37 ve üzeri } & $22-26$ & $1,34225^{*}$ &, 51630 & , 050 \\
\hline & $27-31$ & ,24755 & 40705 & ,929 \\
\hline & $32-36$ &,- 26381 & 45221 & ,937 \\
\hline
\end{tabular}

Tablo 6. Katılımcıların Örgütsel Vatandaşlık Davranış Ölçeği Puanlarının Öğrenim Durumu Değişkenine Göre ANOVA Sonuçlarn

\begin{tabular}{|c|c|c|c|c|c|c|}
\hline & & Kareler Toplamı & $\mathrm{Sd}$ & Kareler Ortalaması & $\mathrm{F}$ & $P$ \\
\hline \multirow{3}{*}{ Örgütsel Gelişime Katkı } & Gruplararas1 & 131,264 & 3 & 43,755 & 1,906 & 131 \\
\hline & Gruplariçi & 3442,632 & 150 & 22,951 & & \\
\hline & Toplam & 3573,896 & & & & \\
\hline \multirow{3}{*}{ Yardımseverlik } & Gruplararası & 30,466 & & 10,155 & 978 & 405 \\
\hline & Gruplariçi & 1557,144 & & 10,381 & & \\
\hline & Toplam & 1587,610 & & & & \\
\hline \multirow{3}{*}{ Kendini Gerçekleştirme } & Gruplararası & 8,314 & & 2,771 & 1,260 & 290 \\
\hline & Gruplariçi & 329,946 & & 2,200 & & \\
\hline & Toplam & 338,260 & & & & \\
\hline \multirow{3}{*}{ Sahiplenme } & Gruplararası & 42,446 & & 14,149 & 3,479 &, 018 \\
\hline & Gruplariçi & 610,048 & & 4,067 & & \\
\hline & Toplam & 652,494 & & & & \\
\hline \multirow{3}{*}{ Centilmenlik } & Gruplararası & 7,266 & & 2,422 & 925 & 430 \\
\hline & Gruplariçi & 392,819 & & 2,619 & & \\
\hline & Toplam & 400,084 & & & & \\
\hline
\end{tabular}

Tabloda görüldüğü gibi yaş açısından örgütsel vatandaşlık ölçeğinin örgütsel gelişime katkı alt boyutunda $\mathrm{F}(3,150)=1,906, \mathrm{p}>0,05$, yardımseverlik alt boyutunda $\mathrm{F}(3,150)=, 405, \mathrm{p}>0,05$, kendini gerçekleştirme alt boyutunda $\mathrm{F}(3,150)=, 290, \mathrm{p}>0,05$, centilmenlik alt boyutunda $\mathrm{F}(3,150)=, 290$, $\mathrm{p}>0,05$ anlamlı farklılığa rastlanmamıştır. Örgütsel vatandaşlık ölçeğinin sahiplenme alt boyutunda $\mathrm{F}(3,150)=3,086 \mathrm{P}<0,05$ anlamlı farklılık görülmüştür. Anlamlı 
farkların elde edilmesinden sonra anlamlılı̆̆ın hangi gruplardan kaynaklandığını tespit etmek için tamamlayıcı testlerden TUKEY Testi kullanılmıştır.

Tablo 7. Örgütsel Vatandaşlık Ölçeği Puanlarnnı Öğrenim Durumuna Göre ANOVA Sonuçlarında Anlamlı Farka İlişkin TUKEY Testi Sonuçları

\begin{tabular}{lllll}
\hline \multirow{2}{*}{ Illköğretim } & & Ort. Fark. & ss & $\mathrm{p}$ \\
\hline \multirow{3}{*}{ Lise } & Lise & $-2,61765^{*}$ &, 89300 &, 020 \\
\cline { 2 - 5 } & Yüksekokul/Üniversite & $-2,62963^{*}$ &, 84587 &, 012 \\
\cline { 2 - 5 } & Yüksek Lisans & $-1,83333$ & 1,16433 &, 396 \\
\hline \multirow{2}{*}{ Yüksekokul/Üniversite } & İlköğretim & $2,61765^{*}$ &, 89300 &, 020 \\
\cline { 2 - 5 } & Yüksekokul/Üniversite &,- 01198 &, 39658 & 1,000 \\
\cline { 2 - 5 } & Yüksek Lisans &, 78431 &, 89300 &, 816 \\
\hline \multirow{2}{*}{ Yüksek Lisans } & Illköğretim & $2,62963^{*}$ &, 84587 &, 012 \\
\cline { 2 - 5 } & Lise &, 01198 &, 39658 & 1,000 \\
\cline { 2 - 5 } & Yüksek Lisans &, 79630 &, 84587 &, 783 \\
\hline & İlköğretim & 1,83333 & 1,16433 &, 396 \\
\cline { 2 - 5 } & Lise &,- 78431 &, 89300 &, 816 \\
\cline { 2 - 5 } & Yüksekokul/Üniversite &,- 79630 &, 84587 &, 783 \\
\hline
\end{tabular}

Tablo görüldüğü gibi katılımcıların öğrenim durumu değişkenine göre algıladıkları örgütsel vatandaşlık alt boyutlarından sahiplenme puanları arasında istatistik olarak anlamlı farklılık vardır. Bu anlamlı farklılık ilköğretim, lise ile üniversite gruplarından kaynaklanmaktadır. Bu gruplarının algıladıkları sahiplenme algısı diğer gruplara göre daha anlamlıdır. Ayrıca sıra ortalamalarına bakıldığında öğrenim durumlarından ilköğretim grubunun diğer gruplara göre sahiplenme algılarının daha yüksek olduğu görülmektedir.

Tablo 8. Katılımcıların Duygusal Zeka Ölçeği Puanlarının Cinsiyet Değişkenine Göre TTesti Sonuçlarn

\begin{tabular}{llllllll}
\hline & Grup & $\mathrm{N}$ & $\mathrm{X}$ & $\mathrm{S}$ & $\mathrm{Sd}$ & $\mathrm{t}$ & $\mathrm{p}$ \\
\hline \multirow{2}{*}{ Duygusal Farkındalık } & Kadın & 50 & 19,16 & 4,10 & 152 &, 175 &, 861 \\
\cline { 2 - 8 } Motivasyon & Erkek & 104 & 19,04 & 4,00 & & \\
\hline \multirow{2}{*}{ Kendini Yönetme } & Kadın & 50 & 19,32 & 3,30 & \multirow{2}{*}{, 098} &, 922 \\
\hline \multirow{2}{*}{ Empati } & Erkek & 104 & 19,27 & 2,85 & & \\
\hline \multirow{2}{*}{ Ilişki Yönetimi } & Kadın & 50 & 18,08 & 3,29 & $-1,242$ &, 216 \\
\cline { 2 - 8 } & Erkek & 104 & 18,70 & 2,71 & & \\
\hline & Kadın & 50 & 18,82 & 2,88 & 1,617 &, 108 \\
\hline & Erkek & 104 & 17,91 & 3,42 & & \\
\hline
\end{tabular}


Analiz sonuçları katılımcıların duygusal zeka ölçeği alt boyutları cinsiyet değişkenine göre duygusal farkındalık, $\mathrm{t}(152)=-, 175, \mathrm{p}>0,05$, motivasyon, $t(152)=-, 922, p>0,05$, kendini yönetme $t(152)=, 216, p>0,05$ ve empati, $\mathrm{t}(152)=, 108, \mathrm{p}>0,05$ arasında anlamlı farklılık olduğunu göstermemektedir. Fakat ilişki yönetimi alt boyutu $\mathrm{t}(152)=-2,179, \mathrm{p}<0,05$ cinsiyete göre anlamlı bir farklılık göstermektedir. Sıra ortalamalarına bakıldığında erkek katılımcıların $(X=17,42)$ kadın katılımcılara $(X=16,04)$ göre daha olumlu olduğu görülmektedir.

Tablo 9. Katılımcıların Duygusal Zeka Ölçeği Puanlarnnın Medeni Durum Değişkenine Göre T-Testi Sonuçlan

\begin{tabular}{|c|c|c|c|c|c|c|c|}
\hline & Medeni Durum & $\mathrm{N}$ & $x$ & $\mathrm{~S}$ & $\mathrm{Sd}$ & $\mathrm{t}$ & $\mathrm{P}$ \\
\hline \multirow{2}{*}{ Duygusal Farkındalık } & Evli & 92 & 19,18 & 3,78 & 152 & 401 & 689 \\
\hline & Bekar & 62 & 18,92 & 4,37 & & & \\
\hline \multirow{2}{*}{ Motivasyon } & Evli & 92 & 19,02 & 3,11 & & $-1,338$ & 183 \\
\hline & Bekar & 62 & 19,68 & 2,77 & & & \\
\hline \multirow{2}{*}{ Kendini Yönetme } & Evli & 92 & 18,68 & 2,98 & & ,958 & 340 \\
\hline & Bekar & 62 & 18,23 & 2,83 & & & \\
\hline \multirow{2}{*}{ Empati } & Evli & 92 & 18,20 & 3,21 & &,- 056 & ,950 \\
\hline & Bekar & 62 & 18,23 & 3,39 & & & \\
\hline \multirow{2}{*}{ İlişki Yönetimi } & Evli & 92 & 17,10 & 3,42 & & ,500 & ,618 \\
\hline & Bekar & 62 & 16,79 & 4,18 & & & \\
\hline
\end{tabular}

Analiz sonuçları katılımcıların duygusal zeka ölçeği alt boyutları medeni durumu değişkenine göre duygusal farkındalık, $\mathrm{t}(152)=-, 401, \mathrm{p}>0,05$, motivasyon, $t(152)=-1,338, p>0,05$, kendini yönetme $t(152)=, 958, p>0,05$ ve empati, $t(152)=-, 056, p>0,05$ ve ilişki yönetimi $t(152)=, 500 p>0,05$ arasında anlamlı farklılık olmadığını göstermektedir.

Tablo 10'da görüldüğü gibi yaş açısından duygusal zeka ölçeğinin duygusal farkındalık alt boyutunda $\mathrm{F}(3,150)=, 993, \mathrm{p}>0,05$, motivasyon alt boyutunda $\mathrm{F}(3,150)=, 369, \mathrm{p}>0,05$, kendini yönetme alt boyutunda $\mathrm{F}(3,150)=1,774$, $p>0,05$, empati alt boyutunda $F(3,150)=1,403, P>0,05$ ve ilişki yönetimi alt boyutunda $\mathrm{F}(3,150)=2,151, \mathrm{P}>0,05$ anlamlı farklılığa rastlanmamıştır. 
Tablo 10. Katılımcılarnn Duygusal Zeka Ölçeği Puanlarnnın Yaş Durumu Değişkenine Göre ANOVA Sonuçlarn

\begin{tabular}{|c|c|c|c|c|c|c|}
\hline & & Kareler Toplamı & sd & Kareler Ortalaması & $\mathrm{F}$ & $\mathrm{P}$ \\
\hline \multirow{3}{*}{ Duygusal Farkındalık } & Gruplararasi & 48,098 & 3 & 16,033 & ,993 & 398 \\
\hline & Gruplariçi & 2420,967 & 150 & 16,140 & & \\
\hline & Toplam & 2469,065 & & & & \\
\hline \multirow{3}{*}{ Motivasyon } & Gruplararas1 & 10,022 & & 3,341 & ,369 & ,775 \\
\hline & Gruplariçi & 1357,407 & & 9,049 & & \\
\hline & Toplam & 1367,429 & & & & \\
\hline \multirow{3}{*}{ Kendini Yönetme } & Gruplararas1 & 44,554 & & 14,851 & 1,774 & 155 \\
\hline & Gruplariçi & 1255,946 & & 8,373 & & \\
\hline & Toplam & 1300,500 & & & & \\
\hline \multirow{3}{*}{ Empati } & Gruplararas1 & 44,787 & & 14,929 & 1,403 & ,244 \\
\hline & Gruplariçi & 1596,563 & & 10,644 & & \\
\hline & Toplam & 1641,351 & & & & \\
\hline \multirow{3}{*}{ İlişki Yönetimi } & Gruplararasi & 87,937 & & 29,312 & 2,151 & ,096 \\
\hline & Gruplariçi & 2043,959 & & 13,626 & & \\
\hline & Toplam & 2131,896 & & & & \\
\hline
\end{tabular}

Tablo 11. Katılımcıların Duygusal Zeka Ölçeği Puanlarnnı İş Deneyimi Değişkenine Göre ANOVA Sonuçlar

\begin{tabular}{|c|c|c|c|c|c|c|}
\hline & & Kareler toplamı & $\mathrm{Sd}$ & Kareler Ortalaması & $\mathrm{F}$ & $\mathrm{p}$ \\
\hline \multirow{3}{*}{ Duygusal Farkındalık } & Gruplararas1 & 86,263 & 3 & 21,566 & 1,349 & 255 \\
\hline & Gruplariçi & 2382,802 & 150 & 15,992 & & \\
\hline & Toplam & 2469,065 & & & & \\
\hline \multirow{3}{*}{ Motivasyon } & Gruplararası & 25,672 & & 6,418 & ,713 &, 584 \\
\hline & Gruplariçi & 1341,757 & & 9,005 & & \\
\hline & Toplam & 1367,429 & & & & \\
\hline \multirow{3}{*}{ Kendini Yönetme } & Gruplararas1 & 38,294 & & 9,573 & 1,130 & ,345 \\
\hline & Gruplariçi & 1262,206 & & 8,471 & & \\
\hline & Toplam & 1300,500 & & & & \\
\hline \multirow{3}{*}{ Empati } & Gruplararas1 & 135,106 & & 33,777 & 3,341 &, 012 \\
\hline & Gruplariçi & 1506,244 & & 10,109 & & \\
\hline & Toplam & 1641,351 & & & & \\
\hline \multirow{3}{*}{ İlişki Yönetimi } & Gruplararas1 & 80,967 & & 20,242 & 1,471 & 214 \\
\hline & Gruplariçi & 2050,929 & & 13,765 & & \\
\hline & Toplam & 2131,896 & & & & \\
\hline
\end{tabular}

Tabloda görüldüğü gibi iş deneyimi açısından duygusal zeka ölçeğinin duygusal farkındalık $\mathrm{F}(3,150)=1,349, \mathrm{p}>0,05$, motivasyon alt boyutunda $\mathrm{F}(3,150)=, 713, \mathrm{p}>0,05$, kendini yönetme alt boyutunda $\mathrm{F}(3,150)=1,130, \mathrm{p}>0,05$, ilişki yönetimi alt boyutunda $\mathrm{F}(3,150)=1,471, \mathrm{p}>0,05$, anlamlı farklılığa rast- 
lanmamıştır. Fakat empati alt boyutunda $F(3,150)=3,341$, p $<0,05$ ve ilişki yönetimi alt boyutunda $F(3,150)=4,318$, $\mathrm{p}<0,05$ anlamlı farklılık görülmüştür. Anlamlı farkların elde edilmesinden sonra anlamlılığın hangi gruplardan kaynaklandığını tespit etmek için tamamlayıcı testlerden Tukey- Testi kullanılmıştır.

Tablo 12. Duygusal Zeka Ölçeği Puanlarnnın İş Deneyimine Göre ANOVA Sonuçlarında Anlamh Farka İlişkin TUKEY Testi

\begin{tabular}{|c|c|c|c|c|}
\hline & Iş Deneyimi & Ort. Fark. & Ss & $\mathrm{p}$ \\
\hline \multirow{4}{*}{1 Yildan Az } & $2-4 Y_{11}$ & 1,14569 & ,84777 & 660 \\
\hline & 5-9 Yil &,- 24275 & 82133 & ,998 \\
\hline & 10-15 Yll & 40909 & ,95865 & ,993 \\
\hline & 16 Yildan Fazla & 2,44697 & ,93846 & ,074 \\
\hline \multirow{4}{*}{ 2-4 Yil } & 1 Yildan Az & $-1,14569$ & ,84777 & ,660 \\
\hline & 5-9 Y1l & $-1,38843$ & ,68869 & 263 \\
\hline & $10-15 Y_{11}$ &,- 73660 & 84777 & ,908 \\
\hline & 16 Yildan Fazla & 1,30128 & 82487 & ,514 \\
\hline \multirow{4}{*}{ 5-9 Y 11} & 1 Yildan Az & ,24275 & ,82133 & ,998 \\
\hline & $2-4 Y_{1}$ & 1,38843 & 68869 & ,263 \\
\hline & $10-15$ Yil & ,65184 & ,82133 & ,932 \\
\hline & 16 Yildan Fazla & $2,68972^{*}$ & 79768 & ,008 \\
\hline \multirow{4}{*}{ 10-15 Yil } & 1 Yildan Az &,- 40909 & ,95865 & ,993 \\
\hline & $2-4 Y_{11}$ & ,73660 & 84777 & ,908 \\
\hline & 5-9 Yil &,- 65184 & ,82133 & ,932 \\
\hline & 16 Yıldan Fazla & 2,03788 & ,93846 & 196 \\
\hline \multirow{4}{*}{16 Yildan Fazla } & 1 Yildan Az & $-2,44697$ & ,93846 & , 074 \\
\hline & $2-4 Y_{11}$ & $-1,30128$ & 82487 &, 514 \\
\hline & 5-9 Y1l & $-2,68972^{*}$ & ,79768 & ,008 \\
\hline & $10-15 Y_{11}$ & $-2,03788$ & ,93846 & 196 \\
\hline
\end{tabular}

Tabloya göre katılımciların empati düzeylerinin 5-9 yıl ve 16 yıldan fazla çalışan grupların diğer gruplara göre daha olumlu olduğu görülmektedir. 
Tablo 13. Örgütsel Vatandaşlık ve Duygusal Zeka Ölçeklerinin Alt Boyutları Arasındaki Korelasyon Analizi Sonuçlan

\begin{tabular}{|c|c|c|c|c|c|c|c|c|c|}
\hline & $\mathrm{X} 1 \quad \mathrm{X} 2$ & $\mathrm{X} 3$ & $\mathrm{X} 4$ & $\mathrm{X} 5$ & Y1 & $\mathrm{Y} 2$ & $\mathrm{Y} 3$ & $\mathrm{Y} 4$ & Y5 \\
\hline \multirow{3}{*}{$\begin{array}{l}\text { Örgütsel } \\
\text { Gelişime Katkı (X1) }\end{array}$} & $1,542^{* *+}$ & $436^{* *}$ & ,122 & $351^{* *}$ & ,137 & $344^{* *+}$ & $278^{* *}$ & $226^{* *}$ &,$- 187^{*}$ \\
\hline & ,000 & ,000 & ,132 & ,000 & ,091 & ,000 & ,000 & ,005 & , 020 \\
\hline & 154 & 154 & 154 & 154 & 154 & 154 & 154 & 154 & 154 \\
\hline \multirow{3}{*}{ Yardımseverlik (X2) } & 1 & $474^{* *}$ & ,291* & ,722* & ,219** & $695^{* *}$ & $334^{* *}$ & $406^{* *}$ & , 083 \\
\hline & & 000 & 000 & ,000 & ,006 & 000 & 000 & 000 & 307 \\
\hline & & 154 & 154 & 154 & 154 & 154 & 154 & 154 & 154 \\
\hline \multirow{3}{*}{ Sahiplenme (X3) } & & 1 & $208^{* *}$ & $493^{* *}$ & $337^{40+}$ & ,712 & $413^{* *}$ & $343^{* * *}$ & $211^{* *}$ \\
\hline & & & , 010 & ,000 & ,000 & , 000 & ,000 & ,000 & ,009 \\
\hline & & & 154 & 154 & 154 & 154 & 154 & 154 & 154 \\
\hline \multirow{3}{*}{ Centilmenlik (X4) } & & & 1 & $225^{* *}$ & ,043 & $277^{*+*}$ & $269^{* *}$ &, $345^{* *}$ & $296^{* *}$ \\
\hline & & & & ,005 & ,597 & ,001 & ,001 & ,000 & ,000 \\
\hline & & & & 154 & 154 & 154 & 154 & 154 & 154 \\
\hline \multirow{3}{*}{$\begin{array}{l}\text { Kendini } \\
\text { Gerçekleştirme (X5) }\end{array}$} & & & & 1 & ,251** & $816^{* *+}$ & ,288** & ,290* & , 148 \\
\hline & & & & & ,002 & , 000 & ,000 & , 000 & ,068 \\
\hline & & & & & 154 & 154 & 154 & 154 & 154 \\
\hline \multirow{3}{*}{ Motivasyon (Y1) } & & & & & 1 & $316^{* * *}$ & $486^{* *}$ & $417^{\text {*** }}$ & $391^{* *}$ \\
\hline & & & & & & ,000 & ,000 & , 000 & , 000 \\
\hline & & & & & & 154 & 154 & 154 & 154 \\
\hline \multirow{3}{*}{$\begin{array}{l}\text { Kendini } \\
\text { Yönetme (Y2) }\end{array}$} & & & & & & 1 & ,291* & $354^{* *}$ & $285^{* *}$ \\
\hline & & & & & & & 000 & 000 & 000 \\
\hline & & & & & & & 154 & 154 & 154 \\
\hline \multirow{3}{*}{$\begin{array}{l}\text { Duygusal } \\
\text { Farkındalık (Y3) }\end{array}$} & & & & & & & 1 & $460^{* *}$ & $335^{* *}$ \\
\hline & & & & & & & & 000 & 000 \\
\hline & & & & & & & & 154 & 154 \\
\hline \multirow{3}{*}{ Empati (Y4) } & & & & & & & & 1 & $289^{* * *}$ \\
\hline & & & & & & & & & ,000 \\
\hline & & & & & & & & & 154 \\
\hline İlişki Yönetimi (Y5) & & & & & & & & & 1 \\
\hline
\end{tabular}

Tabloda görüldüğü gibi örgütsel vatandaşlık ve duygusal zeka envanterlerinin alt boyutları arasındaki korelasyon ilişkisinde yardımseverlik ile ilişki yönetimi (r=722) ve kendini yönetme arasında (r=695) yüksek düzeyde pozitif ve anlamlı bir ilişki vardır. Kendini yönetme alt boyutu ile kendini gerçekleştirme alt boyutu arasında yüksek düzeyde pozitif ve anlamlı bir ilişki vardır $(\mathrm{r}=816)$. Diğer taraftan örgütsel gelişime katkı alt boyutu ile motivasyon alt boyutu düşük düzeyde pozitif yönde anlamlı bir ilişki vardır (r=137). Sahiplenme alt boyutu ile kendini yönetme alt boyutu arasında yüksek düzeyde anlamlı bir ilişki vardır ( $\mathrm{r}=712)$. 


\section{Tartışma Sonuç}

Duygusal zeka ve örgütsel vatandaşlık düzeylerinin bazı değişkenler (cinsiyet, yaş, iş deneyimi, öğrenim durumu) açısından farklılaşmaktadır $\left(\mathrm{H}_{1}\right)$ ve duygusal zeka ile örgütsel vatandaşlık arasında pozitif bir ilişki vardır $\left(\mathrm{H}_{2}\right)$ şeklinde ortaya koyduğumuz hipotezlerimiz doğrultusunda elde edilen bulgular literatür düzeyinde tartıştığımızda bazı çalışmaların bulgularımızı desteklediğini bazılarının ise tezat olduğu görülmüsstür.

Araştırmamızda örgütsel vatandaşlık davranışlarının cinsiyet değişkenine göre anlamlı bir farklılık göstermemektedir. Ilgili literatür incelendiğinde araştırmamızla paralellik gösteren çalışmaların olduğu (Özarslan ve ark,, 2009; Titrek ve ark. 2009; Aksoy, 2011) ve erkekler lehine anlamlı farkl1lık gösteren, çalışmamıza tezat bulguları olan çalışmalarda görülmüştür (Güllü ve Şahin, 2018; Sökmen ve Boylu, 2011; Aksoy, 2012; Ölçüm, 2004). Erkeklerin örgüt içerisinde kadınlara göre daha fazla karar alma ve uygulatma eğiliminde olduklarından örgütsel vatandaşlık davranışarında fark olacağına dair ortaya koyduğumuz hiptezimiz H1 reddedilmiştir. Örgütsel vatandaşlık ölçeği alt boyutları medeni durum değişkenine göre anlamlı bir farklılık göstermemiş olup literatürde paralellik gösteren çalışma bulunmuştur (Gündüz, 2008)

Araştırmamızda örgütsel vatandaşlık ölçeğinin yaş değişkenin de örgütsel gelişime katkı, yardımseverlik ve centilmenlik alt boyutlarında anlamlı farklılığa rastlanmamıştır. Fakat sahiplenme alt boyutunda 22-26 yaş grubu lehine anlamlı farklılık görülmüş̧ür. 22- 26 yaş örgüte yeni katılmayı temsil eden bir yaş grubu olduğundan istek ve çalışma kapasiteleri daha yüksek olduğu ve örgüte daha fazla aidiyet hissetikleri için yüksek yaş gruplarına göre sahiplenme düzeyleri daha yüksek olduğu şeklinde yorumlanabilir. Literatürde bulgumuza paralellik gösteren (Ölçüm, 2004) ve tezat olan çalışmalar görülmüştür (Aksoy,2011). Diğer bir bulgumuzda ise, öğrenim durumu aç1sından örgütsel vatandaşlık ölçeğinin sahiplenme alt boyutunda ilköğretim lehine anlamlı farklılık görülmüştür ve literatürde bulgumuza tezat (Polat ve Celep, 2008) çalışma görülmüştür.

Örgütsel vatandaşlık ölçeği puanlarına dair başka bir bulgumuz ise medeni duruma göre anlamlı farklılık göstermediği yönünde olup lteratürde bulgumuza paralel (Aksoy,2011; Gündüz, 2008) ve tezat olan ( Bolat, 2009) çalışmalar mevcuttur. 
Analiz sonuçları, katılımcıların duygusal zeka ölçeği alt boyutları içerisinde, ilişki yönetimi alt boyutunun cinsiyete göre erkekler lehine anlamlı bir farklılık olduğu göstermiştir. Literatürde spor yöneticilerinin duygusal zeka düzeylerine yönelik yapılan bir araştırmada cinsiyet değişkenine göre anlamlı farklılık bulunmamıştır (Serter ve Biçer, 2019). Diğer taraftan Özdinç ve Bilir'in üst düzey spor örgüt yöneticileriyle yaptığı çalışmada alan yazını incelemiş ve Duygusal zeka skorunun kadın ve erkek test grupları arasında farklılık gösterdiğini öne süren çalışmalar çoğunlukla kadınların lehine bulgular ortaya koyduğunu ve bu durumu bazı araştırmacılar kadının yaratılış itibariyle erkeğe oranla daha duygusal ve anaç oluşuyla ilişkilendirdiklerini belirtmişlerdir (Özdinç ve Bilir, 2016).

Diğer bir bulgumuz duygusal zeka alt boyutundan olan empatinin iş deneyimine göre 5-9 yıl çalışanlar lehine anlamlı farklılık görülmüsstür. Bireyler meslek hayatlarındaki empati düzeyleri çalışma süreleri ilerledikçe azalabileceği kanaatindeyiz. İlgili literatür incelendiğinde bulgularımıza tezat olan çalışmalar (Aksoy, 2011; Adiloğulları, 2013) görülmüştür.

Çalışmamızda duygusal zeka alt boyut puanlarının yaş değişkenine göre anlamlı farklılık göstermediği görülmüştür. Literatürde benzer bulguya rastlanmıştır (Gürbüz ve Yüksel, 2008). Duygusal zekanın kişinin kendinin ve başkalarının duygularını tanıması ve anlaması, duygularını doğru yönetmesiyle tanımlandığından bu davranış bireylerde var ise yaş ile değişmeyeceği şeklinde yorumlanabilir.

Araştırmamızda örgütsel vatandaşlık ile duygusal zeka alt boyutları arasında pozitif ve anlamlı ilişkiler olduğu görülmüştür ve $\mathrm{H}_{2}$ hipotezimiz kabul edilmiştir.

Sonuç olarak örgütsel vatandaşlık ve duygusal zeka ölçeğinin bazı alt boyutlarının cinsiyet, yaş, medeni durum, iş deneyimi ve öğrenim durumu değişkenlerine göre farklılaştığı görüldüğü için $\mathrm{H}_{1}$ hipotezimiz kısmen kabul edilmiştir. 


\title{
EXTENDED ABSTRACT
}

\section{Investigation Of Emotional And Sports Provincial Directorate Employees 'Emotional And Organizational Citizenship Behavior \\ *}

\author{
Sultan Yavuz Eroğlu - Erdem Eroğlu - Servet Reyhan \\ Siirt University
}

Today, it is well known that there are many changes and developments in the fields of political, social, cultural and sports together with globalization. Undoubtedly, these developments and changes are mostly seen in organizations. In order for organizations to survive and achieve success, they need to keep up with this change, adopt continuous innovation, and work with staff doing the right job at the right time. At the same time, since the main source of organizations is human, everyone from the employee to the executive is expected to serve the same purpose in cooperation. The fact that there are at least two people and includes a coordinative situation has brought the human element to the fore in organizations. For this reason, in order for the organizations to survive, the commitment of those working in the organization to the organization is an important factor (Kürekli, 2011; Başaran, 1984; Şimşek, 1999). Accordingly, the concept of organizational citizenship behavior has been brought to the agenda. The relationship of organizational citizenship behavior with many different variables was examined. It is a concept used to express the degree of behavior and belonging to the organization that the individual displays / wants to display for the benefit of the organization. In organizations where the organizational citizenship behavior is bony, the organizational commitment level of the employees is high, their tendency to leave jobs is low, and the potential to exhibit behaviors for the benefit of the organization increases. Organizational citizenship behavior is voluntary individual behavior that is not directly or explicitly defined by the formal reward system, is not compulsive and supports the organization to perform its functions more effectively as a whole (Organ and Dennis, 1997). The basic element required to see the organizational citizenship behavior is to act with the per- 
sonal desire of the employee without coercion. Organizational-selective citizenship behavior is thought to create positive effects by volunteer workers such as low job stress, conflict level, job absenteeism and high performance (Çelik \& Çıra, 2013). Before looking at the definition of emotional intelligence, it would be appropriate to look at the definition of intelligence. Turkish Language Association intelligence; All of human's abilities of thinking, reasoning, perception of objective facts, judgment and deduction are defined as understanding, acumen, zeyreklik, feracet (https://sozluk.gov.tr). Emotional intelligence; It can be defined as the ability to perceive and express emotions, to absorb emotions in thought, to understand and question with emotions, and to regulate emotions in itself and others (Mayer et al. 2004). According to Goleman, emotional intelligence; recognizing and understanding one's feelings for yourself and others; self-motivation; is the ability to manage his emotions correctly in himself and in his relationships (Goleman, 1995). In addition to social benefit, it is considered important for the success of this institution that the employees of sports institutions, which are considered important for the prestige of the country, exhibit organizational citizenship behavior and have mental intelligence behaviors in a hierarchical order. Our research; In line with our hi-potezes, we show that emotional intelligence and organizational citizenship levels differ in terms of some variables (gender, age, work experience, educational status) (H1) and a positive relationship between emotional intelligence and organizational citizenship (H2). and it is aimed to investigate emotional intelligence and organizational citizenship behaviors of the provincial directorate of sports and sports. As the data collection technique in the research, personal information form created by the researchers, "Emotional Intelligence Scale" consisting of 25 expressions developed by Özaslan, Acar B. and Acar C. (2009) to measure the participants' emotional intelligence level, and Morrison to measure Organizational citizenship behaviors. (1994) and an abbreviated form of the organizational citizenship scale developed by Türker, Yenerli and Aksoy (2006). In the analysis of data, ANOVA test was used to determine the difference between more than two independent variables and dependent variables for determining binary comparisons. Pearson correlation analysis was conducted to look for the relationship between the "Organizational Citizenship Behavior" subscales and the "Emotional Intelligence" subscales. As a result; In the analyzes made with the 
sub-dimensions of organizational citizenship, there was no significant difference in the variables of gender, marital status, work experience ( $p>0.05)$, but significant difference in the age variable $(\mathrm{p}<0.05)$. In the results of the analysis conducted with the sub-dimensions of emotional intelligence scale, there was no significant difference in age and marital status variables ( $p>0.05)$, while there was a significant difference $(p<0.05)$ in the variables of gender, education and work experience. In addition, as a result of the correlation analysis, it was observed that there was a low level of positive and significant relationship between emotional intelligence sub-dimensions and organizational citizenship sub-dimensions.

\section{Kaynakça / References}

Adiloğulları, G.E. (2013). Beden eğitimi öğretmenlerinin duygusal zekâ ile mesleki tükenmişlik düzeyleri arasindaki ilişkinin incelenmesi, Yüksek Lisans Tezi, Kahramanmaraş Sütçü İmam Üniversitesi, Kahramanmaraş

Aksoy, S. (2012). Etik liderlik ve orgutsel vatandaşlık davranışlarının örgutsel performansa etkisi uzerine bir araştırma, Yüksek Lisans Tezi, Gebze Yüksek Teknoloji Enstitüsü, Sosyal Bilimler, Enstitüsü, Gebze

Aksoy, Y. (2011). Örgütsel vatandaşlık ve duygusal zekâ davranışları arasındaki ilişkinin incelenmesi: Spor yönetiminde gsgm ve özerk spor federasyonları örneği. Yüksek Lisans Tezi, Gazi Üniversitesi, Ankara

Bolat, O. ve Bolat T. (2008). Otel işletmelerinde örgütsel bağlllık ve örgütsel vatandaşlık davranışı ilişkisi. BAÜ SBED 11(19), 75-94.

Çakar, U. ve Arbak, Y., (2004). Modern yaklaşımlar işığında değişen duygu zeka ilişkisi ve duygusal zeka. Dokuz Eylül Üniversitesi SBE Dergisi, 6(3), 23-48.

Çelik, M. ve Çıra, A. (2013). Örgütsel vatandaşlık davranışının iş performansı ve işten ayrılma niyeti üzerine etkisinde aşırı iş yükünün aracılık rolü. Ege Akademik Bakış Dergisi, 13(1), 11-20.

Goleman D. (1995). Emotional intelligence. New York: Bantam Boks. 86-91

Güllü, S., Şahin, S. (2018). Bir spor kurumunda örgütsel çekicilik algisi ile örgütsel vatandaşlık davranışının incelenmesi. Turkish Studies, 13(26), 637-654

Gündüz G. (2008). İşletmelerde Kurumsallaşma uygulamalarına yönelik çalışan tutumlarının örgütsel vatandaşlık ile ilişkisine yönelik bir uygulama. Yüksek Lisans Tezi. İstanbul: Yıldız Teknik Üniversitesi, Sosyal Bilimler Enstitüsü, İstanbul. 
Gürbüz, S., Yüksel, M. (2008). Çalışma ortamında duygusal zeka: iş performansı, iş tatmini, örgütsel vatandaşlık davranışı ve bazı demografik özelliklerle ilişkisi, Doğuş Üniversitesi Dergisi, 9(2) , 174-190

Karayol, M. (2019). Kişilik ve iş değerlerinin kurumsal bă̆lllık açısından önemi: Gençlik ve Spor Bakanlığı çalışanları. (1. Baskı), Ankara: Nobel Akademik Yayıncilik. 122-123.

Kürekli, D. (2011). Türkiye'deki spor teşkilatlarinda çalişan personelin farkli kadro pozisyonlarina ve kurum statüsüne göre örgütsel vatandaşlik davranişi farkliliklarinin belirlenmesi. Yüksek Lisans Tezi, Niğde Üniversitesi Sosyal Bilimler Enstitüsü, Niğde.

Mayer, J, D., Salovey P., ve Caruso D.R. (2004). A furter consideration of the issues of emotional intelligence. New hampshire. Psychological Inquiry, 8(3), 74-87

Ölçüm, Ç.M. (2004). Örgütsel vatandaşlık davranışı. Ankara: Nobel Yayın Dağııı. 29-37

Organ, D. W. ve Dennis W. (1997). Organizational citizenship behavior: It's constructs clean-up time, Human Performance, 10(2), 85-97.

Özarslan, Ö.B., Acar, A.B. ve Acar, C.A. (2009). Duygusal zeka ve örgütsel vatandaşlık davranışı arasındaki ilişkinin incelenmesine yönelik bir araştırma. Yönetim, 20(64) 98-111.

Özdinç, Ö. ve Bilir, P. (2016). Üst düzey spor örgüt yöneticilerinin duygusal zeka özelliklerini belirlemeye yönelik bir çalışma. Spor Bilimleri Dergisi, 27(1), 27-39

Özen, G., Timurkaan Akçınar, S., Güllü, M., Timurkaan, H. S., Meriç, F., Uğraş, S. ve Çelik Çoban, D. (2018). Spor lisesi eğitsel oyunlar. (2. Baskı) Ankara. Devlet Kitapları. 69.

Polat, S. ve Celep, C. (2008). Ortaöğretim öğretmenlerinin örgütsel adalet, örgütsel güven, örgütsel vatandaşlık davranışlarına ilişkin algıları. Kuram ve Uygulamada Ĕ̆itim Yönetimi, 54, 307-331.

Serter, K., Biçer, T. (2019). Yerel yönetimler ve gençlik hizmetleri spor müdürlüğ̈̈'nde görev yapan spor yöneticilerinin duygusal zekâ düzeyleri ile mutlulukları arasındaki ilişkinin incelenmesi. Avrasya Spor Bilimleri Araştırmaları, 4(2), 66-82.

Şimşek, Ş. (1999). Yönetim ve organizasyon. (5. Bask1) Ankara; Nobel Yayın Dağıtım. 137, 138, 301, 302. 
Sökmen, A. ve Boylu, Y. (2011). Örgütsel vatandaşlık davranışı cinsiyete göre farklılık gösterir mi? Otel işletmeleri açısından bir değerlendirme. Gaziantep Üniversitesi Sosyal Bilimler Dergisi, 10(1), 147-163.

Titrek, O., Bayrakçı, M. ve Zafer, D. (2009). Öğretmenlerin örgütsel vatandaşlık davranışlarına ilişkin görüşleri. Akademik Bakış, 17, 1-7.

Yüksel, M., (2006). Duygusal zeka ve performans ilişkisi. Yüksek Lisans Tezi, Atatürk Üniversitesi, Sosyal Bilimler Enstitüsü, Erzurum.

\section{Kaynakça Bilgisi / Citation Information}

Yavuz Eroğlu, S., Eroğlu, E. ve Reyhan, S. (2020). Gençlik hizmetleri ve spor il müdürlüğü çalışanlarının, duygusal zeka ile örgütselvatandaşlık davranışlarının incelenmesi. OPUS-Uluslararası Toplum Araştırmaları Dergisi , 15(23), 1725-1745. DOI: 10.26466/opus. 624515 